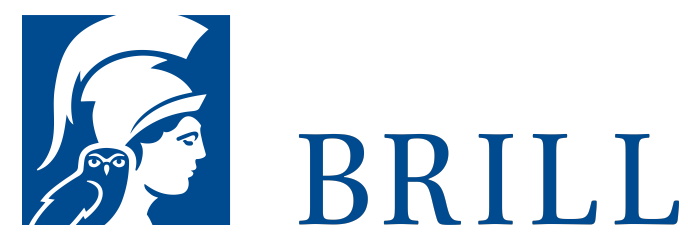

\title{
The Fiery Holy Spirit
}

The Spirit's Relationship with Judgment in Luke - Acts

Author: Jonathan Kienzler

The baptism with the Spirit and fire has been a major area of study by theologians and has been pursued by the historical church seeking God's holiness and power; yet its relationship to judgment has often been ignored. This book explores the Holy Spirit's relationship with judgment in Luke-Acts through seven texts: Luke 3:16-17; 12:8-10; Acts 5:1-11; 7:51; 8:18-23; 13:9-11; 28:25-28. In these texts, the Holy Spirit is connected with fire, unforgiveness, deception, resistance, greed, blindness, or condemnation. In each instance, Luke's presentation is examined to determine the Spirit's role in the process of judgment. Through the Spirit, Jesus judges, cleanses, purges, and divides his people from the world. Luke portrays the Spirit as the executive power of Jesus' reign as judge, exposing, opposing, and condemning those who reject the gospel.

Readership

This important treatment of an under-studied aspect of the work of the Holy Spirit according to Luke-Acts will be useful to New Testament scholars and students, particularly those interested in pneumatology.

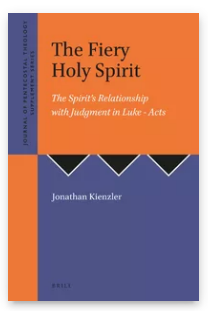

Pages: 256 pp.

Language:

English

Subjects:

General,

Theology and

World

Christianity,

General,

Religious

Studies

Publisher: Brill

Series:

Journal of

Pentecostal

Theology

Supplement

Series, Volume:

44

E-Book (PDF)

Released online:

29 Jan 2020

ISBN: 978-90-

04-39720-O

List price

USD $\$ 133.00$

Paperback

Publication date:

o1 Jan 2015

ISBN: 978-1-

905679-25-6

List price

USD \$46.oo 
Jonathan Kienzler, PhD 2012, University of Aberdeen, is the Biblical Studies Coordinator at Vanguard College, Edmonton, Alberta. He is married to Naomi, and they have three children.

For more information see brill.com

Order information: Order online at brill.com +44 330 333 0049 | customerservices@brill.com Submission information: brill.com/authors

Titles published by Brill | Fink, Brill | mentis or Brill | Schöningh: +49(o)71 5413279216 | brill@brocom.de 